\title{
Community and Socioeconomic Factors Associated with COVID-19 in the United States: \\ Zip code level cross sectional analysis
}

Running title: Socio-demographic risk factors for COVID-19

Avirup Guha, MD*1, Janice M. Bonsu, MPH*², MPH, Amit Kumar Dey, MBBS ${ }^{3}$, Daniel

Addison, $\mathrm{MD}^{4}$

*Contributed Equally

All authors have read and approved this manuscript.

${ }^{1}$ Harrington Heart and Vascular Institute, Case Western Reserve University, Columbus, OH,

USA

${ }^{2}$ The Ohio State University Medical Center, Columbus, OH, USA

${ }^{3}$ Division of Cardiology, National Heart, Lung and Blood Institute, Bethesda, MD

${ }^{4}$ Division of Cardiology, The Ohio State University Medical Center, Columbus, OH, USA

Word Count: 1,955

Tables: 2 tables ( 3 tables in supplement)

Concept and design: $\mathrm{AG}$, and DA.

Acquisition, analysis, or interpretation of data: $\mathrm{AG}, \mathrm{JB}$, and $\mathrm{AD}$.

Drafting of the manuscript: AG, JB and DA.

Critical revision of the manuscript for important intellectual content: All authors.

Statistical analysis: AG.

Administrative, technical, or material support: AG, and DA.

Supervision: DA. 
medRxiv preprint doi: https://doi.org/10.1101/2020.04.19.20071944; this version posted April 22, 2020. The copyright holder for this preprint (which was not certified by peer review) is the author/funder, who has granted medRxiv a license to display the preprint in perpetuity. All rights reserved. No reuse allowed without permission.

Funding: This work was supported in part by NIH grant P30 CA016058, and K12-CA133250

(DA) grants.

Disclosures: All authors have reported that they have no relationships relevant to the contents of this paper to disclose.

\section{Address for correspondence:}

Daniel Addison, MD

Division of Cardiovascular Medicine,

Davis Heart \& Lung Research Institute,

473 West 12th Avenue, Suite 200,

Columbus, OH, 43210

Phone: 614-685-6161

Email: daniel.addison@osumc.edu 


\begin{abstract}
Background: Multiple reports have pointed towards involvement of community and socioeconomic characteristics of people in the United States may be associated with COVID-19 cases and deaths.
\end{abstract}

Methods: In this study, zip-code level data from 5 major metropolitan areas, was utilized to study the effect of multiple demographic \& socioeconomic factors - including race, age, income, chronic disease comorbidity, population density, number of people per household on number of positive cases and ensuing death. Adjusted linear regression analysis using 13 to 16 such variables was performed.

Results: Overall, 442 zip codes reporting 93,170 positive COVID-19 cases and 138 zip codes reporting mortality ranging from 0 to 25 were included in this study. A multivariable linear regression model noted that $1 \%$ increase in the proportion of residents above the age of 65 years, proportion of African American residents, proportion of females, persons per household and population density of the zip code increased the proportion of positive cases by $0.77 \%, 0.23 \%$, $1.64 \%, 1.83 \%$ and $0.46 \%$ respectively $(\mathrm{P}<0.01)$ with only population density remaining significant in zip codes with greater than median number of cases. In zips with greater than median number of deaths, no community/socio-economic factor contributed significantly to death.

Conclusion: This study gives early signals of gender, and racial inequalities while providing overwhelming evidence of how population density may contribute to an increase in the number of positive cases of COVID-19. 
medRxiv preprint doi: https://doi.org/10.1101/2020.04.19.20071944; this version posted April 22, 2020. The copyright holder for this preprint (which was not certified by peer review) is the author/funder, who has granted medRxiv a license to display the preprint in perpetuity.

\section{Introduction}

On March 11, 2020 the World Health Organization (WHO) declared the severe acute respiratory syndrome coronavirus 2 (SARS-CoV-2) a global pandemic (1). The impact of the novel coronavirus 2019 (COVID-19) has disrupted global markets, healthcare systems, and societies. The Johns Hopkins Coronavirus Resource Center, which tracks cases in real-time, has reported over 2,394,000 confirmed global cases, with over 164,000 deaths - nearly 35,000 in the United States alone (2). Economists liken the impact of this crisis on global societies to that at the end of World War II and estimate that it will take the United States (U.S.) and Eurozone three years to recover from COVID-19 (3).

With an increasing number of confirmed U.S. cases, COVID-19 is reminiscent of other infectious disease epidemics before it, with inequities in the prevalence of viral infection a growing concern. Historically, the HIV epidemic nearly exclusively impacted those who faced economic adversity and had lower levels of educational attainment (4). The relationship between neighborhood and area effects on health has been widely established (5). During this COVID-19 pandemic, reports on racial disparities have emerged, with reports of infection rates more than 3fold higher in predominantly African American counties in the U.S. than in predominantly White counties (6). This is concerning given the potentially devastating consequences of this infection and the limited therapeutic options available.

Historically, many of these populations have shared a higher burden of chronic health factors linked with discrepancies in diseases outcomes. Yet, whether these factors actually affect COVID-19 related outcomes is largely unknown. In our study, we hypothesized that using zip code level data in 5 major metropolitan areas, we would observe that multiple socioeconomic 
medRxiv preprint doi: https://doi.org/10.1101/2020.04.19.20071944; this version posted April 22, 2020. The copyright holder for this preprint

(which was not certified by peer review) is the author/funder, who has granted medRxiv a license to display the preprint in perpetuity.

All rights reserved. No reuse allowed without permission.

factors - including race, age, income, chronic disease comorbidity, population density, number of people per household - impact the risk of COVID-19 infections.

\section{Methods:}

\section{Data Source}

Authors collected data zip code level data on 4/11/2020 for the City of New York including all boroughs, Chicago, Richmond county of Detroit, Kings County of Seattle, Miami-Dade County. All data sources are publicly available and the corresponding URLs are listed in supplemental

\section{Table 1.}

\section{Primary Outcome}

The outcomes of interest for zip code level data for the various locations was the number of positive cases and reported causes of specific mortality.

\section{Covariates}

The zip code level data was obtained from the censusreporter.org website for 446 zip codes spanning the areas listed above. Specific metrics collected were proportion of Whites, African Americans, and Hispanics, population density reported as people per square mile, proportion of females, median age in years, proportion of those older than 65 years, median household income in dollars, proportion of those below poverty line, persons per household, proportion of married, median house value in dollars, proportion of those with bachelor's degree, and proportion of English speaking. Information on chronic disease from a uniform source was not available. Short-term complications for diabetes and chronic obstructive pulmonary disease (COPD) or asthma in older adults reported as an observed rate per 100,000 was collected for the New York 
medRxiv preprint doi: https://doi.org/10.1101/2020.04.19.20071944; this version posted April 22, 2020. The copyright holder for this preprint (which was not certified by peer review) is the author/funder, who has granted medRxiv a license to display the preprint in perpetuity.

All rights reserved. No reuse allowed without permission.

zip codes. Diabetes-related hospitalizations and asthma related emergency room visits reported as per 10,000 population were collected for the Chicago zip codes. Temperature on March 15, 2020 was obtained from the National Oceanic and Atmospheric Administration (NOAA) website however this was city/county specific and only used for adjustment as warm (1) for Miami and cold (0) for other zip codes. Additionally, county level data for hypertension hospitalization per 1,000 population and cancer per 100,000 population was obtained from CDC website. This was dichotomized for those above and below the median of each metric and used only for adjustment. All the covariate sources are listed in supplemental table 2.

\section{Statistics}

Zip code level data used total number of positive cases and deaths from COVID-19 as continuous variables. All variables were assessed with Shapiro-Wilk test and visual histogram check for normality. All zip codes with at least 1 case or 1 death were included in the respective models. Non-normal variables including the dependent variables above were log transformed. Interactions were assessed in the first adjusted model and were dropped after a likelihood ratio test. Multicollinearity was addressed by performing ridge regression technique where the ridge parameter was adjusted at 0.004 after root mean square error comparison. The final linear regression model presented the log transformed dependent and independent variables, the interpretation was presented as percent change in independent variable required for $1 \%$ change in number of cases or deaths. All inferential linear model designs were presented in supplemental

\section{table 3.}

Sensitivity analysis for all positive cases was performed by adding comorbidities of hypertension and cancer was performed. Additionally, similar analysis for comorbidities of diabetes and 
medRxiv preprint doi: https://doi.org/10.1101/2020.04.19.20071944; this version posted April 22, 2020. The copyright holder for this preprint (which was not certified by peer review) is the author/funder, who has granted medRxiv a license to display the preprint in perpetuity.

All rights reserved. No reuse allowed without permission.

asthma as described above was performed for zip codes in Chicago and New York. Additional sensitivity analysis was done for zip codes above median number of cases and deaths for the city/county of origin of the zip code.

Alpha for the study was set at 0.01 and analysis was performed in SAS 9.4 Cary NC.

\section{Results:}

Overall, as of 04/11/2020 there were 442 zip codes reporting 93,170 positive COVID-19 cases. The range of cases spanned from 0 to 1,728 per zip code. Only the zip codes in Oakland county of Detroit and King's County in Seattle reported mortality. Overall, 138 zip codes reported mortality ranging from 0 to 25 dead.

Among the 442 zip codes studied the median age was $38.2(34.8$ - 42$)$ years, $51 \%(50 \%$ - 53\%) were female, $45 \%$ of zip code residents were white $(13 \%-70 \%), 6 \%$ of zip code residents were African American (2\% - 21\%) and $15 \%$ of zip code residents were Hispanic $(6 \%-40 \%)$. Other demographics of the 443 zip codes are presented in table 1.

\section{Modelling for positive cases}

In a multivariable linear regression model (table 2) it was noted than proportion of residents above the age of 65 years, proportion of African American residents, proportion of females, persons per household and population density of the zip code was significantly associated with increased likelihood of positive cases in a zip code $(\mathrm{P}<=0.01)$.

In a sensitivity analysis using dichotomous hypertension and cancer county level data the associations noted above remain (table 2). On further sensitivity analysis of NYC and Chicago 
medRxiv preprint doi: https://doi.org/10.1101/2020.04.19.20071944; this version posted April 22, 2020. The copyright holder for this preprint (which was not certified by peer review) is the author/funder, who has granted medRxiv a license to display the preprint in perpetuity.

All rights reserved. No reuse allowed without permission.

zip codes it was clear that proportion of residents above the age of 65 and population density continued to be significantly associated with increased likelihood of positive cases. Among the zip codes with greater than median number of cases (129), only population density was associated with increase in case. For $1 \%$ increase in population density there was $0.27 \%(0.13 \%$ $0.40 \%)$ increase in number of cases $(\mathrm{P}=0.0002)$. All the 4 models mentioned here are presented in supplemental table 3 .

\section{Modelling for mortality}

Moreover, in a multivariable linear regression model (table 2) proportion of residents above the age of 65 years, and proportion of females in a zip code was associated with increased likelihood of COVID-19 related mortality in a zip code $(\mathrm{P}<=0.01)$. However, there was no such association noted in zip codes with greater than median number of deaths (2).

\section{Discussion}

Our findings hold a mirror revealing yet another example of social inequities and disease. This study evaluated COVID-19 cases and mortality rates, integrating the data with reported socioeconomic measures by zip code. We demonstrate that zip codes with a greater proportion of residents above 65 years of age, African American residents, persons per household, and population density were significantly associated with an increased likelihood of COVID-19 cases. After sensitivity analysis, population density remained the factor most significantly associated with COVID-19 cases. These results highlight the importance of social distancing or lack thereof in poorer neighborhoods while giving early signals of racial inequalities which has been noted in other infectious disease and chronic disease epidemiology. 
medRxiv preprint doi: https://doi.org/10.1101/2020.04.19.20071944; this version posted April 22, 2020. The copyright holder for this preprint (which was not certified by peer review) is the author/funder, who has granted medRxiv a license to display the preprint in perpetuity.

All rights reserved. No reuse allowed without permission.

The COVID-19 related health disparities and inequities are not entirely unfamiliar to health practitioners in the U.S. The HIV epidemic remains one of the greatest public health challenges faced in the modern world. In survival analyses, a racial divide was demonstrated in HIV outcomes, with an increasingly disproportionate burden borne by African Americans (7). Additionally, reports of socioeconomic disparities and HIV prevalence has been well reported, with associations including age, wealth, household expenditure, and rural versus urban residence $(4,8)$. Like other preliminary reports, our analysis of the COVID-19 pandemic has also revealed age and race to be positive predictors in COVID-19 cases $(6,9)$. However, when biologic factors such as age and race were held constant, like the HIV epidemic, we found other significant variables in the structural environment that impacted the rate of COVID-19 cases. The impact of socioeconomic disparities on health has been well documented and established, revealing that those with the lowest income and who were least educated were consistently least healthy (10, 11), with correlations present down to the zip code level (12). Our results suggest that even though race, age, and gender were noted initially, zip code level population density is most significant.

There's a correlation between overcrowding and the historic spread of infectious disease.

The influenza pandemic of 1918, popularly known as the Spanish Flu, killed more than 50 million people worldwide (13). Analysis of the specific factors that made that influenza especially catastrophic was overcrowding, which increased both risk of flu by 10 -fold and severity by 5-fold (14). In fact, records from an "open air" hospital in Boston, Massachusetts found that a combination of fresh air, sunlight, and reusable face masks substantially reduced deaths among some patients and new infections among medical staff (15). Social distancing has remained an important way of combating the spread of COVID-19. To date, in the United States, 
medRxiv preprint doi: https://doi.org/10.1101/2020.04.19.20071944; this version posted April 22, 2020. The copyright holder for this preprint (which was not certified by peer review) is the author/funder, who has granted medRxiv a license to display the preprint in perpetuity.

All rights reserved. No reuse allowed without permission.

all 50 governors have declared states of health emergencies. Officials have implemented recommendations around social distancing, which includes the closing of nonessential businesses, closure of schools, and the implementation of stay at home orders (16). Targeted social distancing has been established as an effective way to reduce viral transmission, with a previous study of the 1957-58 influenzas showing a reduction in attack rate by $>90 \%$ (17). However, social distancing is more difficult for some populations than others. Our data demonstrate that among the zip codes with the highest population density, COVID-19 cases were greater. This is unsurprising and likely due to the historical impact of population density and overcrowding observed in past pandemics.

There are certain limitations which should be considered while considering the aforementioned results. The study results have potentially changed in terms of reported number of cases and deaths however, the models generated, and effects described are expected to potentially remain the same given the overall power of the study and multiple sensitivity analysis performed. Even though multiple socio-demographic variables were utilized, the authors acknowledge that this study should not be interpreted out of context of currently available data. Specifically, chronic conditions increase the risk of acquiring and dying from COVID-19 and in this study such adjustment was limited from such adjustments. Another metric about the number of positive cases may point towards discrepant testing/swab availability. However, the authors feel that socio-demographic factors may be responsible for such discrepancy in testing and would contribute to multicollinearity and not change the effect noted above.

\section{Conclusion}


medRxiv preprint doi: https://doi.org/10.1101/2020.04.19.20071944; this version posted April 22, 2020. The copyright holder for this preprint (which was not certified by peer review) is the author/funder, who has granted medRxiv a license to display the preprint in perpetuity.

All rights reserved. No reuse allowed without permission.

Race has long been used as a proxy for socioeconomic status, with growing pressure to specifically name the variables truly at play. In this analysis, even though signals regarding the role of race and gender were noted initially, after sensitivity analysis, we found that the most significant predictor of a positive COVID-19 case was the structural environment of an individual, namely, the population density within their zip code. This reality makes preventative measures, such as social distancing policies, difficult to implement. This research highlights the need for community-specific outreach and interventions to address the COVID-19 pandemic.

\section{References}

1. Cucinotta D, Vanelli M. WHO Declares COVID-19 a Pandemic. Acta Biomed. 2020;91(1):157-60.

2. Dong E, Du H, Gardner L. An interactive web-based dashboard to track COVID-19 in real time. The Lancet Infectious Diseases.

3. McKinsey \& Company. COVID-19: Global health and crisis response. COVID-19: Briefing materials; 2020.

4. Pellowski JA, Kalichman SC, Matthews KA, Adler N. A pandemic of the poor: social disadvantage and the U.S. HIV epidemic. The American psychologist. 2013;68(4):197209.

5. Diez Roux AV. Investigating neighborhood and area effects on health. Am J Public Health. 2001;91(11):1783-9.

6. Yancy CW. COVID-19 and African Americans. JAMA. 2020. 
medRxiv preprint doi: https://doi.org/10.1101/2020.04.19.20071944; this version posted April 22, 2020. The copyright holder for this preprint

(which was not certified by peer review) is the author/funder, who has granted medRxiv a license to display the preprint in perpetuity.

All rights reserved. No reuse allowed without permission.

7. Morris M, Kurth AE, Hamilton DT, Moody J, Wakefield S. Concurrent partnerships and HIV prevalence disparities by race: linking science and public health practice. American journal of public health. 2009;99(6):1023-31.

8. Bärnighausen T, Hosegood V, Timaeus IM, Newell M-L. The socioeconomic determinants of HIV incidence: evidence from a longitudinal, population-based study in rural South Africa. AIDS (London, England). 2007;21 Suppl 7(Suppl 7):S29-S38.

9. Grasselli G, Zangrillo A, Zanella A, Antonelli M, Cabrini L, Castelli A, et al. Baseline Characteristics and Outcomes of 1591 Patients Infected With SARS-CoV-2 Admitted to ICUs of the Lombardy Region, Italy. JAMA. 2020.

10. Braveman PA, Cubbin C, Egerter S, Williams DR, Pamuk E. Socioeconomic disparities in health in the United States: what the patterns tell us. American journal of public health. 2010;100 Suppl 1(Suppl 1):S186-S96.

11. Adler NE, Newman K. Socioeconomic Disparities In Health: Pathways And Policies. Health Affairs. 2002;21(2):60-76.

12. Krieger N, Chen JT, Waterman PD, Soobader MJ, Subramanian SV, Carson R. Choosing area based socioeconomic measures to monitor social inequalities in low birth weight and childhood lead poisoning: The Public Health Disparities Geocoding Project (US). Journal of Epidemiology and Community Health. 2003;57(3):186.

13. Taubenberger JK, Morens DM. 1918 Influenza: the mother of all pandemics. Emerging infectious diseases. 2006;12(1):15-22.

14. Aligne CA. Overcrowding and Mortality During the Influenza Pandemic of 1918. American journal of public health. 2016;106(4):642-4. 
medRxiv preprint doi: https://doi.org/10.1101/2020.04.19.20071944; this version posted April 22, 2020. The copyright holder for this preprint (which was not certified by peer review) is the author/funder, who has granted medRxiv a license to display the preprint in perpetuity. All rights reserved. No reuse allowed without permission.

15. Hobday RA, Cason JW. The open-air treatment of pandemic influenza. American journal of public health. 2009;99 Suppl 2(Suppl 2):S236-S42.

16. Gostin LO, Wiley LF. Governmental Public Health Powers During the COVID-19 Pandemic: Stay-at-home Orders, Business Closures, and Travel Restrictions. JAMA. 2020.

17. Glass RJ, Glass LM, Beyeler WE, Min HJ. Targeted social distancing design for pandemic influenza. Emerging infectious diseases. 2006;12(11):1671-81.

Table 1: Baseline demographics of zip codes used in the study (current as of 4/11/2020)

\begin{tabular}{|l|l|l|}
\hline Variable & $\begin{array}{l}\text { Zips reporting positive cases } \\
(\mathbf{N}=\mathbf{4 4 2})\end{array}$ & $\begin{array}{l}\text { Zips reporting death } \mathbf{N}= \\
\mathbf{1 3 8})^{*}\end{array}$ \\
\hline $\begin{array}{l}\text { Median Age (median, IQR, } \\
\text { years) }\end{array}$ & $38.2(34.8-42)$ & $39.9(37.1$ \\
\hline $\begin{array}{l}\text { Proportion of those older } \\
\text { than 65 years (median, IQR, } \\
\text { \%) }\end{array}$ & $14(11-17)$ & $14(12-17)$ \\
\hline $\begin{array}{l}\text { Proportion of those females } \\
\text { (median, IQR, \%) }\end{array}$ & $51(50-53)$ & $51(50-52)$ \\
\hline $\begin{array}{l}\text { Baseline White (median, } \\
\text { IQR, \%) }\end{array}$ & $45(13-70)$ & $75(58-85)$ \\
\hline $\begin{array}{l}\text { Baseline African American } \\
\text { (median, IQR, \%) }\end{array}$ & $6(2-21)$ & $3.5(1-10)$ \\
\hline $\begin{array}{l}\text { Baseline Other Race } \\
\text { (median, IQR, \%) }\end{array}$ & $35(19-55)$ & $18.5(10-32)$ \\
\hline $\begin{array}{l}\text { Baseline Hispanic ethnicity } \\
\text { (median, IQR, \%) }\end{array}$ & $15(6-40)$ & $68,3(3-8)$ \\
\hline $\begin{array}{l}\text { Median household income } \\
\text { (median, IQR, US dollars) }\end{array}$ & $69,414(50,108-120,104)$ & $10.8)$ \\
\hline Proportion of those below & $12.1(7.3-20.3)$ & $109,847)$ \\
\hline
\end{tabular}




\begin{tabular}{|c|c|c|}
\hline $\begin{array}{l}\text { poverty line (median, IQR, } \\
\% \text { ) }\end{array}$ & & \\
\hline $\begin{array}{l}\text { Median house value } \\
\text { (median, IQR, US dollars) }\end{array}$ & $412,700(256,700-600,600)$ & $340,700(231,300-496,800)$ \\
\hline $\begin{array}{l}\text { Persons per household } \\
\text { (median, IQR) }\end{array}$ & $2.7(2.3-2.9)$ & $2.5(2.3-2.7)$ \\
\hline $\begin{array}{l}\text { Population density } \\
\text { (median, IQR, people per } \\
\text { square mile) }\end{array}$ & $10,564(3,682-31,291)$ & $2,660(1,243-4,697)$ \\
\hline $\begin{array}{l}\text { Proportion of married ( } \\
\text { mean }+/-\mathrm{SD}, \% \text { ) }\end{array}$ & $46.2+/-11.5$ & $56+/-11.3$ \\
\hline $\begin{array}{l}\text { Proportion of those with } \\
\text { bachelor's degree (median, } \\
\text { IQR, \%) }\end{array}$ & $37.5(25.1-57.8)$ & $47.5(32.8-65.2)$ \\
\hline $\begin{array}{l}\text { Proportion of english } \\
\text { speaking (median, IQR, \%) }\end{array}$ & $65(40.4-80)$ & $84.8(73-92)$ \\
\hline \multicolumn{3}{|l|}{ New York Zip codes } \\
\hline $\begin{array}{l}\text { Short term complications } \\
\text { for diabetes (median, IQR, } \\
\text { per } 100,000 \text { population) }\end{array}$ & $77.1(42.7-130.7)$ & N/A \\
\hline $\begin{array}{l}\text { Chronic obstructive } \\
\text { pulmonary disease or } \\
\text { asthma in older adults } \\
\text { (median, IQR, per } 100,000 \\
\text { population) }\end{array}$ & $395.9(278.3-605.0)$ & N/A \\
\hline \multicolumn{3}{|l|}{ Chicago Zip Codes } \\
\hline $\begin{array}{l}\text { Diabetes related } \\
\text { hospitalizations (median, } \\
\text { IQR, per } 10,000 \text { population) }\end{array}$ & $20.9(11.5-32.7)$ & N/A \\
\hline $\begin{array}{l}\text { Asthma related emergency } \\
\text { room visits (median, IQR, } \\
\text { per } 10,000 \text { population) }\end{array}$ & $26.2(11.2-40.9)$ & N/A \\
\hline
\end{tabular}

*including zips reporting 0 deaths 
medRxiv preprint doi: https://doi.org/10.1101/2020.04.19.20071944; this version posted April 22, 2020. The copyright holder for this preprint (which was not certified by peer review) is the author/funder, who has granted medRxiv a license to display the preprint in perpetuity.

Table 2 Linear Regression Modeling Specific Results of significant variables. All proportions presented are multivariable with models presented in supplemental table 3

\begin{tabular}{|c|c|c|c|c|}
\hline Model & $\begin{array}{l}\text { Variable } \\
\text { Significant }\end{array}$ & $\begin{array}{l}\text { Parameter } \\
\text { estimate } \\
\text { (confidence } \\
\text { interval) }\end{array}$ & P-value & Interpretation \\
\hline \multirow[t]{6}{*}{$\begin{array}{l}\text { Natural Log } \\
\text { of all Cases } \\
\text { (logcases) }\end{array}$} & logage & $\begin{array}{l}0.77(0.56- \\
0.99)\end{array}$ & $<0.001$ & $\begin{array}{l}\text { For } 1 \% \text { increase in proportion of those } \\
\text { above } 65 \text { years in a zip number of cases } \\
\text { increased by } 0.77 \%\end{array}$ \\
\hline & logblack & $\begin{array}{l}0.23(0.13- \\
0.34)\end{array}$ & $<0.001$ & $\begin{array}{l}\text { For } 1 \% \text { increase in proportion of African } \\
\text { Americans in a zip number of cases } \\
\text { increased by } 0.23 \%\end{array}$ \\
\hline & logeng & $\begin{array}{l}-0.40(-0.68 \\
--0.12)\end{array}$ & 0.005 & $\begin{array}{l}\text { For } 1 \% \text { increase in proportion of native } \\
\text { english speakers in a zip number of } \\
\text { cases decreased by } 0.4 \%\end{array}$ \\
\hline & logfem & $\begin{array}{l}1.64(0.42- \\
2.87)\end{array}$ & 0.009 & $\begin{array}{l}\text { For } 1 \% \text { increase in proportion of } \\
\text { females in a zip number of cases } \\
\text { increased by } 1.64 \%\end{array}$ \\
\hline & logperhou & $\begin{array}{l}1.83(1.07- \\
2.59)\end{array}$ & $<0.001$ & $\begin{array}{l}\text { For } 1 \% \text { increase in number of people per } \\
\text { household in a zip number of cases } \\
\text { increased by } 1.83 \%\end{array}$ \\
\hline & logpopden & $\begin{array}{l}0.46(0.36- \\
0.56)\end{array}$ & $<0.001$ & $\begin{array}{l}\text { For } 1 \% \text { increase in population density in } \\
\text { a zip number of cases increased by } \\
0.46 \%\end{array}$ \\
\hline \multirow[t]{2}{*}{$\begin{array}{l}\text { Natural Log } \\
\text { of died } \\
\text { (logdied) }\end{array}$} & logage & $\begin{array}{l}1.02(0.25- \\
1.8)\end{array}$ & 0.01 & $\begin{array}{l}\text { For } 1 \% \text { increase in proportion of those } \\
\text { above } 65 \text { years in a zip number of deaths } \\
\text { among those infected with COVID- } 19 \\
\text { increased by } 1.02 \%\end{array}$ \\
\hline & logfem & $\begin{array}{l}7.11(2.47- \\
11.76)\end{array}$ & 0.003 & $\begin{array}{l}\text { For } 1 \% \text { increase in proportion of } \\
\text { females in a zip number of deaths } \\
\text { among those infected with COVID-19 } \\
\text { increased by } 7.11 \%\end{array}$ \\
\hline $\begin{array}{l}\text { Natural Log } \\
\text { of all Cases } \\
\text { (logcases) } \\
\text { adjusted for } \\
\text { county level }\end{array}$ & logage & $\begin{array}{l}0.66(0.45- \\
0.86)\end{array}$ & $<0.001$ & $\begin{array}{l}\text { For } 1 \% \text { increase in proportion of those } \\
\text { above } 65 \text { years in a zip number of cases } \\
\text { increased by } 0.66 \%\end{array}$ \\
\hline
\end{tabular}




\begin{tabular}{|c|c|c|c|c|}
\hline \multicolumn{5}{|l|}{ htn and canc } \\
\hline & logblack & $\begin{array}{l}0.19(0.09- \\
0.29)\end{array}$ & 0.0003 & $\begin{array}{l}\text { For } 1 \% \text { increase in proportion of African } \\
\text { Americans in a zip number of cases } \\
\text { increased by } 0.19 \%\end{array}$ \\
\hline & logfem & $\begin{array}{l}1.72(0.56- \\
2.87)\end{array}$ & 0.004 & $\begin{array}{l}\text { For } 1 \% \text { increase in proportion of } \\
\text { females in a zip number of cases } \\
\text { increased by } 1.72 \%\end{array}$ \\
\hline & logperhou & $\begin{array}{l}1.51(0.78- \\
2.23)\end{array}$ & $<0.001$ & $\begin{array}{l}\text { For } 1 \% \text { increase in number of people per } \\
\text { household in a zip number of cases } \\
\text { increased by } 1.51 \%\end{array}$ \\
\hline & logpopden & $\begin{array}{l}0.37(0.27- \\
0.47)\end{array}$ & $<0.001$ & $\begin{array}{l}\text { For } 1 \% \text { increase in population density in } \\
\text { a zip number of cases increased by } \\
0.37 \%\end{array}$ \\
\hline \multirow[t]{4}{*}{$\begin{array}{l}\text { Natural Log } \\
\text { of Cases in } \\
\text { NYC }\end{array}$} & logage & $\begin{array}{l}0.68(0.39- \\
0.98)\end{array}$ & $<0.001$ & $\begin{array}{l}\text { For } 1 \% \text { increase in proportion of those } \\
\text { above } 65 \text { years in a NYC zip number of } \\
\text { cases increased by } 0.68 \%\end{array}$ \\
\hline & logdiab & $\begin{array}{l}0.40(0.24- \\
0.57)\end{array}$ & $<0.001$ & $\begin{array}{l}\text { For } 1 \% \text { increase in observed rate of } \\
\text { short term complications in diabetics per } \\
100,000 \text { in NYC zip number of cases } \\
\text { increased by } 0.4 \%\end{array}$ \\
\hline & logperhou & $\begin{array}{l}1.37(0.38- \\
2.36)\end{array}$ & 0.007 & $\begin{array}{l}\text { For } 1 \% \text { increase in number of people per } \\
\text { household in a NYC zip number of cases } \\
\text { increased by } 1.37 \%\end{array}$ \\
\hline & logpopden & $\begin{array}{l}0.42(0.25- \\
0.59)\end{array}$ & $<0.001$ & $\begin{array}{l}\text { For } 1 \% \text { increase in population density in } \\
\text { a NYC zip number of cases increased by } \\
0.42 \%\end{array}$ \\
\hline \multirow[t]{2}{*}{$\begin{array}{l}\text { Natural Log } \\
\text { of Cases in } \\
\text { CHI }\end{array}$} & logage & $\begin{array}{l}0.57(0.18- \\
0.96)\end{array}$ & 0.005 & $\begin{array}{l}\text { For } 1 \% \text { increase in proportion of those } \\
\text { above } 65 \text { years in a CHI zip number of } \\
\text { cases increased by } 0.57 \%\end{array}$ \\
\hline & logperhou & $\begin{array}{l}4.57(3.28- \\
5.87)\end{array}$ & $<0.001$ & $\begin{array}{l}\text { For } 1 \% \text { increase in number of people per } \\
\text { household in a CHI zip number of cases } \\
\text { increased by } 4.57 \%\end{array}$ \\
\hline
\end{tabular}

canc $=$ cancer per 100,000 population in county treated as 0 for less than median and 1 for greater than median, $\mathrm{CHI}=$ chicago zip codes, htn $=$ Hypertension hospitalization per 1,000 population in a county treated as 0 for less than median and 1 for greater than median 
logage $=$ natural log of proportion of those older than 65 years,

logblack = natural log of proportion african americans,

logcase $=$ natural log of total positive cases (not including 0 case zips),

$\log$ diab $=$ natural $\log$ of diabetes comorbidity as explained in supplemental table 3 ,

logdied = natural log of total cause specific death (not including zips with missing death data and with 0 deaths),

logeng = natural log of proportion of english speaking,

$\operatorname{logfem}=$ natural $\log$ of proportion of females,

logperhou $=$ natural log of persons per household,

logpopden = natural log of population density reported as people per square mile, 